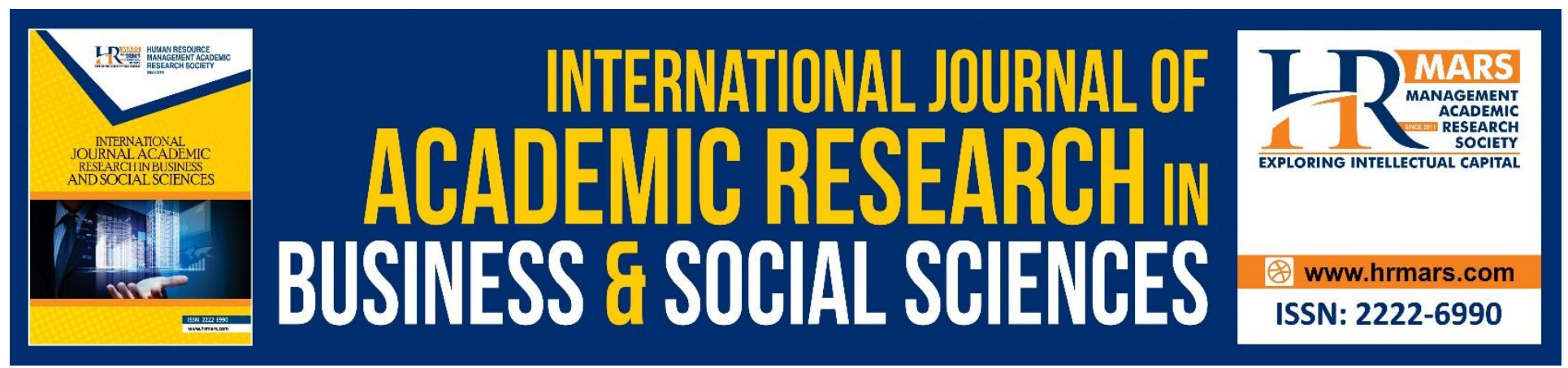

\title{
Personal Identity From an Islamic Perspective
}

\section{Mohamad Zaidin Mohamad, Ahmad Zahid Salleh, Ahmad Fauzi Hasan, Sofyuddin Yusof, Mohd Faiz Hakimi Mat Deris, Ezad Azraai Jamsari}

To Link this Article: http://dx.doi.org/10.6007/IJARBSS/v10-i10/7932

DOI:10.6007/IJARBSS/v10-i10/7932

Received: 08 August 2020, Revised: 28 August 2020, Accepted: 20 September 2020

Published Online: 18 October 2020

In-Text Citation: (Mohamad, et. al, 2020)

To Cite this Article: Mohamad, M. Z., Salleh, A. Z., Hasan, A. F., Yusof, S., Deris, M. F. H. M., \& Jamsari, E. A. (2020). Personal Identity From an Islamic Perspective. International Journal of Academic Research in Business and Social Sciences. 10(10), 199-207.

\section{Copyright: (c) 2020 The Author(s)}

Published by Human Resource Management Academic Research Society (www.hrmars.com)

This article is published under the Creative Commons Attribution (CC BY 4.0) license. Anyone may reproduce, distribute, translate and create derivative works of this article (for both commercial and non-commercial purposes), subject to full attribution to the original publication and authors. The full terms of this license may be seen

at: http://creativecommons.org/licences/by/4.0/legalcode

Vol. 10, No. 10, 2020, Pg. 199 - 207

http://hrmars.com/index.php/pages/detail/IJARBSS

JOURNAL HOMEPAGE

Full Terms \& Conditions of access and use can be found at http://hrmars.com/index.php/pages/detail/publication-ethics 


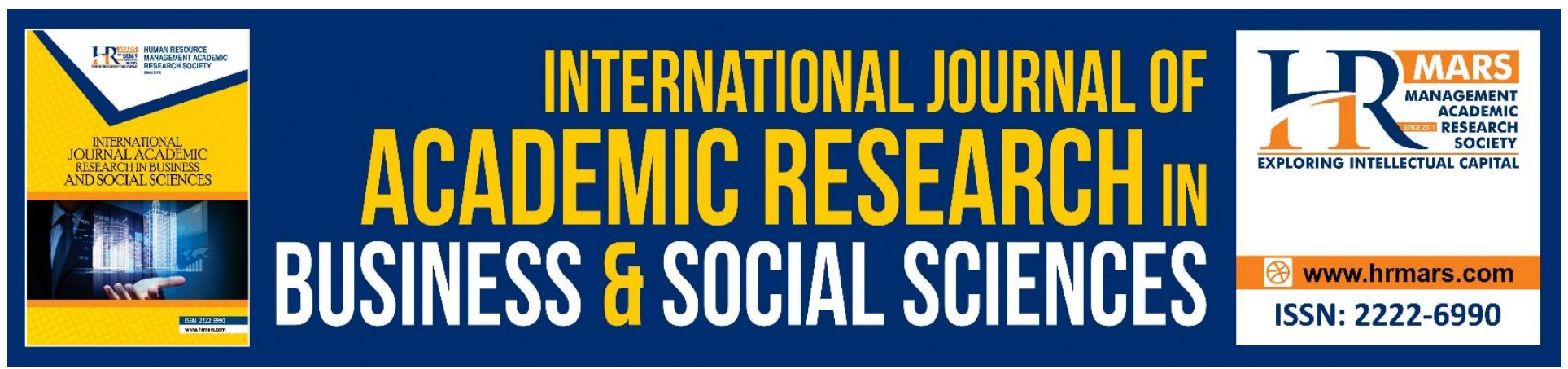

\title{
Personal Identity From an Islamic Perspective
}

\author{
Mohamad Zaidin Mohamad ${ }^{1}$, Ahmad Zahid Salleh ${ }^{1}$, Ahmad Fauzi \\ Hasan ${ }^{1}$, Sofyuddin Yusof ${ }^{1}$, Mohd Faiz Hakimi Mat Deris ${ }^{1}$, Ezad \\ Azraai Jamsari² \\ ${ }^{1}$ Universiti Sultan Zainal Abidin (UniSZA), ${ }^{2}$ Universiti Kebangsaan Malaysia (UKM)
}

\begin{abstract}
From an Islamic perspective, personal identity is an important issue because it involves a Muslim's strength and profoundness towards his religious beliefs. However, the current scenario shows that Muslims are increasingly distancing themselves from religious beliefs due to the influence of temptations and challenges offered by the world today. This study intended to examine personal identity in more detail by focusing on discussions pertaining to its definition, criteria as well as challenges in efforts to consolidate the Islamic identity. This was a qualitative study that used the content analysis method on various reference materials. Findings show that the personal identity issue should be a priority for Muslims, especially for rulers and religious scholars. Suitable strategies and approaches should be designed as soon as possible so that Muslims stop being mesmerized by worldly developments and stop distancing themselves from the sacred teachings delivered by the Prophet SAW.
\end{abstract}

\section{Introduction}

The Prophet SAW had hinted about Islam's loss of identity among Muslims. The Prophet SAW exhorted, "You will follow the road of those before you, step by step, a forearm's length by a forearm's length and if one of them falls into a monitor lizard's hole surely you will follow suit and if one of them is joined by his wife on the pathway, surely you will follow suit" (al-Hakim, 1983). In one narration, we asked, "Are they the Jews and the Christians? HE answered, "who else if not the Jews and Christians" (al-Tabarani, t.th.).

Hence, a keen intellect will be able to assert that the Islamic identity is an important fundamental element that helps build strength and profoundness in the Islamic community when confronted with the challenges and tests of contemporary life. This is the reason why the Prophet SAW had touched on this matter from the beginning.

\section{Definition of The Islamic Identity}

The word 'identity' according to the Cambridge Dictionary means, "who a person is, or the qualities of a person or group that make them different from others". The word huwiyyah (identity) from the 
INTERNATIONAL JOURNAL OF ACADEMIC RESEARCH IN BUSINESS AND SOCIAL SCIENCES Vol. 10, No. 10, 2020, E-ISSN: 2222-6990 @ 2020 HRMARS

linguistic aspect means, "a deep sense of fundamentals". Some believe that it is the "tasghir" from the word huwah (هوة) (Jamil, 1994).

Identity, from a philosophical perspective, refers to the reality or actuality of a thing and the difference in values compared to others. It is also known as having a holistic personality (wihdat aldhat). This means that it is equal to the term "philosophy", which means "he is he", referring to the stability and sustainability of original characteristics although there are external changes. The essence of the matter is similar although there are changes to the surroundings (Ibn Manzur, 1414H).

Ibn Hazm was of the view that identity refers to "only the facts of something and not anything else". Moreover, between identity (huwiyyah) and the others (ghayriyyah), there is no intermediary medium that can be accepted by the human mind. Thus, what exits from one part enters into the other part, which is between huwayyah and ghayriyyah (Ibn Hazm, t.th).

Briefly, Islamic identity means a Muslim's faith and his pride in believing in Islam as well as respecting the values of the Islamic civilisation and culture, accentuate Islamic teachings, possess the freedom to practice either as an individual or in a community, implementing religious responsibilities and the obligation to preach to the human community (al-Nuri, 2009).

Regrettably, some writers and academicians have only briefly or superficially discussed identity. They only marginally discussed identity without touching on its contents from the aspects of Islam and faith. Sometimes they have even gone out of context. They have also narrowed down the meaning of identity by centring on Arabic values and several Arabic-related characteristics of civilization, culture and the arts. Discussions were later narrowed down to Arabic racial ideologies. Thinking patterns such as these are indeed dangerous for the profoundness and unity of Muslims. Arab racism is a political movement that is based on ideologies such as bigotry and the asabiyyah spirit, which calls for the glorying of the Arab race as well as forming a rule based on blood relations, language and history, while totally ignoring religious affiliations (al-Jahni, 1420H).

The emergence of this movement was partly pioneered by parties who were hostile towards Islam and wanted to create a barrier to the thought of unifying the Muslims. Indirectly making the racist ideology a second weapon to stab the Muslims after the collapse of the Caliphate in the hands of Ataturk in 1924.

The most evident characteristic of Arab racist ideology is that it existed at the same time when there was an emergence of idiosyncratic calls that strayed away from seeking a practical solution to rebuild the unity of the ummah. The "Arab sentiment" was the main factor that had expedited this thinking in the minds of Muslims. However, in reality, those who advocated this thinking did not build a system or a government that controlled the Muslims based on racism. Conversely, what we hear is monarchy, socialism, democracy and others. This shows that sovereign racist values cannot possibly build Muslims and their civilization (Jabir, 2011).

The next problem related to racism and identity concerns the Arabs who formed a racial group that has its own geographical space but is not united under the same historical and cultural patronage. Each remote area, which has its own history and cultural system, is frequently bound by its own situations, customs and legacies, hence, even though they share a similar language, it cannot bridge the gap between one group and another due to different dialects and pronunciations (Jabir, 2011). This situation not only affects the Arabs but can happen to most ethnic groups, including the Malays in the Malay Archipelago. 
INTERNATIONAL JOURNAL OF ACADEMIC RESEARCH IN BUSINESS AND SOCIAL SCIENCES Vol. 10, No. 10, 2020, E-ISSN: 2222-6990 @ 2020 HRMARS

\section{Characteristics of An Islamic Identity}

The identity of a certain group of humans should have certain characteristics to enable it to be permanent and competitive. These characteristics are summarised according to three elements, namely trust, history and culture, which include the mother tongue, knowledge and art, literature, customs (uruf) and culture. An examination of Islamic identity reveals three elements, as mentioned above.

\section{Trust}

Trust here means religion according to the aspects of thinking, syariah, faith and morality. Hence, the first thing that should be of priority in an Islamic identity is the merging of oneself with faith, which is translated as the show of loyalty towards faith as well as abiding by its demands. Islamic faith is the main component in a Muslim's identity and personality. It is the highest and most noble component in a person's identity. It mergers oneself to a perfect religion, the most noble scripture bestowed to the most noble Messenger in the most noble language through the most noble angel in the most noble world during the most noble month on the most noble night, which was the night of al-Qadr, with the most noble syariat and the most accurate indicator.

Hence, if a Muslim attests to the monotheism of Allah SWT, that the Prophet is the Messenger, practice the religion with knowledge, awareness and faith and take the exhortations of Allah SWT ("verily my prayers, my worship, my life and my death is only for Allah SWT") as the constitution and law of life, then one is a Muslim who possess a strong and profound identity. Islam has placed religion as the first characteristic of a person's identity, the fundamentals in the issue of al-wala' and al-bara' (loyalty and betrayal). It clothes Islamic identity and acts as its main teachings. Islamic identity forbids its subjects from behaving according to an unlslamic identity because it is a form of lie and betrayal. Moreover, lies and betrayals are major transgressions in Islam (Nordin et a.I, 2015). The al-Quran has made this element a form of defence for its subjects due to what had happened to other subjects who were united by religion that helped form their identity.

Religion is something that is comprehensive and inseparable because everything is because of Allah SWT, either prayers, worship, life or death. Whoever seeks a religion besides Islam will not be accepted. Islam is the physical and spiritual forms of religious teachings, the core and subsidiary elements that form the basis of Islamic identity as well as the privilege enjoyed by individuals and the Islam community. It is the characteristics of the privilege, either from the aspects of resources, time, place or layout. It differs from other celestial religions that have been corrupted as well as other creations by various schools of thought. Based on these features, Muslims are those who pray as how we pray, face the kiblat that we face, eat what we slaughtered, accept Allah SWT as their God, Islam as their religion and the Prophet Muhammad SAW as their Prophet (al-Masiri, 2009).

\section{History}

Verily subjects without a history are subjects without a future, or in short, subjects without an identity. In reality, there are no subjects that exist without a history. Each subject has a history, either individually or as a community. Hence, the issue is not about the history but how the history is preserved, its glory days and decline recorded as well as the benefits, wisdom (ibrah) and lessons learned from what had happened. There is a group of humans 
who do not have a noble history; they endeavour to glorify their history, write books to showoff the splendour of their history and there are some who steal the history of others.

History has shown that there are Muslims who possess a strong, noble and effective identity because their history differs from that of others. Their history starts with the creation of humans. It is evident in the manhaj of the al-Quran, which is displayed in historical events that prove it did not begin by the delegation of the Prophet SAW in Mecca but with the history of the Prophets that began during the time of Adam AS. The al-Quran has embedded the importance of history in the souls of Muslims, the need to feel noble about what happened throughout history and turn it into lessons to be learned, which is through the stories about various Prophets as well as the agreement that one bears witness that Allah SWT is the God in the afterlife (al-Masiri, 2009).

3. Culture

Culture, according to Islamic understanding, refers to social science, literature and the mother tongue. One grave error was when some writers presumed that Islamic identity is a part of culture-based identity. In reality, the actual culture that becomes our identity should not deviate from the Islamic values format. Culture should not be led neither lead a person and its indicator is the syariat. Whatever is consistent with syarak can be accepted and whatever contradicts the syarak should be rejected. This refers to the apex of Islamic identity. In short, religion shapes culture and not vice versa.

Although language acts to preserve and be a medium to culture, it also preserves and binds unity amongst Muslims, which allows each individual to communicate and express cultural values. Meanwhile, Arabic, which is the language of the al-Quran, is the fundamental element and feature held by Muslims. Neglecting this language means neglecting the religion. Hence, learning and preserving the Arabic language is compulsory, as what Ibn Taimiyyah said, "Arabic is part of religion, knowing it is compulsory because understanding the al-Quran and Sunnah is compulsory. An obligation that cannot be performed without a particular thing makes that thing mandatory" (Ibn Taymiyyah, 1998).

Among the elements that form culture are knowledge, artistic heritage and ethics. This differs between one community and another in the Islamic world but eventually it is grouped in a complex manner under a similar Syariah framework or mould. This also happens in the relationship between uruf and customs. Some have been certified by syari'e evidence (dalil) as either being compulsory (wajib) or recommended (sunat) and there are some that have been denied by syarak as being forbidden (haram) or permitted (makruh). For example, to discard what is ritually unclean (najis) and prohibited from performing the tawaf while being naked. Hence, whatever is deemed appropriate by syarak cannot become inappropriate and vice versa. For example, the act of exposing one's aurat (the intimate part of the human body) is deemed inappropriate when the divine revelation (wahyu) was delivered, therefore it cannot be deemed as appropriate in the coming generations.

There are customs and traditions that are not recognised by syarak as well as not denied by syari'e evidence (dalil), which is permanent, unchanged and irreplaceable, such as the instinct to eat and drink and have sex, to look and discuss, walk, to be angry and sleep. These things are reason for establishing the laws (hukum). The evaluation by syarak whether something is appropriate or inappropriate is not subject to its original features but is based on its implications and consequences in the future. For example, the desire to eat, which is satisfied 
INTERNATIONAL JOURNAL OF ACADEMIC RESEARCH IN BUSINESS AND SOCIAL SCIENCES Vol. 10, No. 10, 2020, E-ISSN: 2222-6990 @ 2020 HRMARS

through forbidden means, is deemed to be inappropriate and if it is achieved through halal means, then it is deemed appropriate. Similarly, walking and moving, as when one walks to fulfil an obligation (religious) is evaluated as appropriate, whereas walking to carry out an act of vice is deemed inappropriate.

Sometimes customs change and are not static, which cause the law to change as well, such as a woman exposing her head (the whole head or to be scarfless) to a man. At a certain time and place it is presumed to be inappropriate for those who possess moral values and have gained the trust and respect of others, whereas at another place and time that act could be evaluated differently. Hence, in these cases, the syarak follows the uruf and customs (Iwad bin Muhammad al-Qarni, t.th, http://www.saaid.net/book/18/9556.pdf).

\section{Aspects That Help Form an Islamic Identity}

Sayid Sabiq, as mentioned by Abu Bakar (1976), stated that there are seven main strengths in a Muslim needed to rebuild an Islamic identity based on the al-Quran and al-Sunnah.

i. Strength in Beliefs (akidah) refers to the trust that blends with unsuspicious and undoubtful confidence towards Allah SWT, who owns everything and there is no human that can influence this trust and confidence.

ii. Strength of Jihad refers to upholding and defending the right to own a life that is good, noble and free.

iii. Strength of knowledge from an Islamic perspective. Knowledge refers to all types of knowledge that encourage humans to achieve happiness in this world and in the afterlife. Knowledge is a unique tool that motivates and guides a person to introspect and enslave oneself solely because of Allah SWT. It is something that is sacred and valuable in a Muslim's life. What is important in Islam is that knowledge and worship move hand-in-hand (Omar, S.H.S. et al, 2017). Those who have knowledge are given the highest position by Allah SWT and the angels as well as a special position after the prophets, as exhorted by Allah SWT in Surah al-Mujadila, verse 11, meaning: -

"O you who have believed, when you are told, "Space yourselves" in assemblies, then make space; Allah will make space for you. And when you are told, "Arise," then arise; Allah will raise those who have believed among you and those who were given knowledge, by degrees. And Allah is Acquainted with what you do"

iv. Strength of morality and identity. Morality is a symbol of a strong belief. Beliefs and morality are integrated. The process of building perfect human moral values depends on the process of forming perfect beliefs. A strong belief safeguards humans from all sorts of dangers in this world and in the afterlife. Based on this premise, development and progress in this world should not be an excuse for moral and civilizational decay (Ghani et al., 2016).

v. Strength of community bonding as well as frequent and consistent efforts to assist the community to uphold the fundamentals of freedom and equality according to syariat Islam. All this is intended to achieve happiness for all of humankind. The show of care and concern is fundamental in strengthening the Islamic community institution (Ghani et al., 2015).

vi. Strength of peace refers to combined efforts to ensure that aspects of unity-based mutual respect are implemented. Peaceful relations are not only limited amongst Muslims but transverses other civilizations too (Salleh et al., 2015; Salleh \& Zakariya, 2012). This fundamental element rejects 
extreme ways of thinking and actions that only disrupt the peace process and jeopardise the sanctity of Islam (Adam et al., 2016). Hence, Islam respects other religious beliefs and rejects the forcing of Islamic beliefs onto others (Yusob et al., 2017).

vii. Economic strength refers to the consistent search for richness and obtaining it by benefiting from the natural resources and riches found on this earth using methods based on syariat to be used fairly and wisely. Basically, all parties agree that poverty and misery lead towards instability in life and eventually weaken the value of human identity (Hussin et al., 2018).

\section{Threats Towards the Islamic Identity}

Islamic identity has always been a target since the first message was delivered by the Prophet SAW, whereby the polytheists (musyrikin) and hypocrites (munaficun) had combined to exterminate and halt Islamic preaching. Over time and changes in dynasties and its rulers, the attacks had not stopped but became fierce and vicious, with the climax occurring at the present time where enemies are not hesitant in eliminating the religion and its core values in order to eradicate the Islamic identity. The strategy is to follow their plan as follows: -

1. Weaken the belief and cause a crisis to the faith

2. Create conspiracies and sabotage the Arabic language

3. Divide religion according to the outer and inner elements

4. Seize the Islamic identity and shred it to pieces

5. Laud the right for freedom of speech by the Muslimah and trick them

6. Keep Muslims busy with entertainment and vice

7. Control secularism and empower the spirit of globalisation and Westernisation

8. Intensive efforts to revive fairy tales in the form of idolatry, superstition and polytheism

9. Eradicate the effects of history and historical legacies that show the historical truth

10. Activate Christianity by targeting the poor and the sick

11. Take advantage of the economic factor to eliminate the identity

12. Wage a psychological war assisted by various destructive mediums

\section{Conflict Between an Islamic Identity and Loyalty Towards to The Mother Land}

In this crisis there are two terms that some groups try to mix up. The first term is loyalty to one's country and the second is love one's country. The difference between the two is huge.

Loving one's country is an old issue that has existed since humans emerged whereby it is human instinct to love the place where one lives, the place where one lived during his childhood days. It is a sacred and a noble moral value, which are not in conflict with Islamic identity. Moreover, a Muslim with a true heart is one who loves his country and always endeavours to produce the best, while avoiding anything deleterious to the land he loves.

The crisis that leads to confusion is about the meaning of loyalty to one's country, which has a new meaning. It first emerged after the fall of the Islamiah Caliphate, which saw the land of the Muslims divided into smaller countries. It is easy to exploit this term to raise issues related to contentions and the Asabiyyah spirit between the Ummahs because this term estranges and distances its relations with the bond between religion and beliefs. Conversely, it emphasises on the ratio between the place, group of humans, culture, customs, feelings about history and sacrifices because the country is separated from the fabric of religion. 
This leads to a merging of a universal identity into a specific and narrow identity. The emergence of the Egypt identity, Algerian identity or Iraq identity was manipulated by the Asabiyyah spirit, which was the agent and main driver of sectorial spirit and the formation of individual identities that could cause crises between one another due to minor skirmishes.

Therefore, we say that the mother land that we love is Mecca, Madinah and Baitul Maqdis. Besides these places, we cannot be overly proud (Asabiyyah) of it except if we admit out of love, which is instinctual, that the place is our mother land where we were brought up and are familiar with the life there (al-Ghanam, 2019)

\section{The Dangers of Liberalism to Islamic Identity}

Everyone knows that liberalism is a way of thinking created by the West and it is the last product to come out from the closets of philosophy and Western thinking. This is the most successful type of thinking to have influenced the Muslims when they first emerged after lengthy efforts had witnessed failures during that period. Liberalism came to correct many types of thinking, such as communism, capitalism, secularism and others. From another perspective, liberalism came to replace the conservative identity with the Western identity. Regardless of Arab or Islamic identities, liberalism had long tried to eradicate Islamic identity and its teachings.

Liberalism intended to encounter the unification of races and form a divided society with individuals separated from one another, with no significance or issues that can unite them, as well as nothing that can make decisions for them except their own sensory faculties. There is no objective except to free oneself from any sort of encumbrance. More dangerously, liberal thinking aims to exterminate all elements that bind communities together, either positive or negative elements.

Besides that, this type of thinking intends to eliminate the Islamic identity as well as eliminate the feeling of enmity towards any form of colonialism. The best example would be what happened in Iraq and Afghanistan, where it can be seen that liberal thinkers were the first to brand the fighters from these countries as terrorists and justify their actions as fighting against terrorism while spreading democracy (Mohamad et al., 2014).

\section{Conclusion}

It can be concluded that from an Islamic perspective, identity is the core value of strength and what differentiates one ethnic group from another in this world. Without this value, Muslims have no privileges and strength compared to other ethnic groups. Hence, Islamic identity must be evaluated and analysed from time to time so that it is always preserved and put in its proper place.

\section{Acknowledgement}

Special thanks to Research Management, Innovation \& Commercialization Centre (RMIC) and University Sultan Zainal Abidin (UniSZA) for funding this research (R0034-R026).

\section{Corresponding Author}

Mohamad Zaidin Mohamad

Universiti Sultan Zainal Abidin, Gong Badak Campus, 21300 Kuala Terengganu, Malaysia. 
INTERNATIONAL JOURNAL OF ACADEMIC RESEARCH IN BUSINESS AND SOCIAL SCIENCES

Vol. 10, No. 10, 2020, E-ISSN: 2222-6990 @ 2020 HRMARS

\section{References}

Ghani, N., Azmi, N., Puteh, D. A. H. M. (2013). The impact of the tourism industry on the community's well-being on Langkawi and Redang Islands, Malaysia. American-Eurasian Journal of Sustainable Agriculture. 7(4): 389-396.

Bakar, H. (1976). Syarah falsafah Islam. Kelantan : Pustaka Aman Sdn. Bhd.

Hussin, M. F., Salleh, M. A., Hehsan, A., \& Junaidi, J. (2018). The roles of non-state actors in eradating poverty in Malaysia. IOP Conference Series: Earth and Environmental Science. 175(1): 012166.

Adam, F., Muhad, F. N., Wahid, N. A., Yusoff, Z., Baru, R., Kadir, F. K. A., \& Salleh, M. A. (2016). Radical religious extremism within the context of Islamic discussion. Man in India. 96(12): 5373-5379.

Ghani, N. A., Yassin, S. M., Ahmad, W. I., Abdullah, W. S. (2010). Island communities: Level of quality of life, settlements and housing in Pulau Perhentian, Terengganu, Malaysia. Social Sciences. 5(5): 433-439.

Ghani, N. A., Chik, W. M., Abdullah, B., \& Ghazalli, F. S. M. (2015). Social support for the HIV/AIDS Community: A Case Study of Komuniti Cakna Terengganu (KCT), Malaysia. Mediterranean Journal of Social Sciences. 6(1S1): 232-241.

Al-Hakim. (1983). al-Mustadrak 'al al-Sahihayn. Beirut: Dar al-Kutub al-Ilmiyyah.

Al-Jahni. (1420H). al-Mawsu'ah al-Muyassarah fi al-Adyan wa al-Mazahib wa al-Ahzab al-Mu'asirah. Beirut: Dar al-Nadwah li al-Tiba'ah wa al-Nashr wa al-Tawzi'.

Jamil, S. (1994). al-Mu'jam al-Falsafi. Beirut: al-Sharikah al'Alamiyyah li al-Kutub.

Al-Masiri. (2009). al-Huwayyah wa al-Harakiyyah al-Islamiyyah. Beirut: Dar Fikr.

Mohamad, M. Z., Mujani, W. K., Rozali, E. A., Omar, S. H. S., Othman, M. S., Rahman, S. M. A., Ali, M. S., Ali, E. M. T. E., Yusoff, K., \& Hashim, J. (2014). The negative impact of religious pluralism on the Islamic society in Malaysia. Social Sciences (Pakistan). 9(3): 153-156.

Nordin, N., Daud, N., Ahmad, A. A., Bakar, N. A., Ali, E. M. T. E. (2015). Gharar in forward and futures contracts? Mediterranean Journal of Social Sciences. 6(2): 435-441.

Al-Nuri, K. (2009). al-Huwayyah al-Islamiyyah fi Zaman al- 'Awlamah. Iraq: Diwan al-Waqf al-Sunni.

Omar, S. H. S., Fadzli, A., Baru, R., \& Norhashimah, Y. (2017). Tokku Paloh's manual on sufi practices in Ma'arij Al-Lahfan Li Al-Taraqqi Ila HaqaiqAl-'irfan. Pertanika Journal of Social Sciences and Humanities. 25(Special Issue): 1-11.

Rahman, A. H. A., Said, S., Salamun, H., Aziz, H., Adam, F., \& Ahmad, W. I. W. (2018). Sustainable development from Islamic perspective. International Journal of Civil Engineering and Technology. 9(4): 985-992.

Salleh, M. A., \& Zakariya, H. (2012). The American evangelical Christians and the U.S. Middle east policy: A case study of the Christians United for Israel (CUFI). Intellectual Discourse. 20(2): 139163.

Salleh, M. A., Hussin, M. F., Azeez, Y. A., Adam, F., \& Muhamad, N. H. N. (2015). The emergence of non-state actors in enhancing Malaysia's relationship with the GCC countries. Pertanika Journal of Social Sciences and Humanities. 23(Special Issue11): 267-280.

Yusob, M. M. L., Salleh, M. A., Ariffin, M. R. A., \& Mohamed, A. M. H. (2017)a. International religious freedom act 1998 and the issues of religious freedom in Muslim countries. Pertanika Journal of Social Sciences and Humanities. 25(October): 231-239. 